Yuzuncu Y1l University
Jitps://dergipark.org.tr/en/pub/yyutbd

Research Article

\title{
The Impacts of Clove Extract Incorporated Gelatine/Glycerol Based Edible Film Covered PET Packaging on the Ready-to-eat 'Wonderful' Pomegranate (Punica granatum L.) Arils
}

\section{İbrahim KAHRAMANOĞLU*1}

\author{
${ }^{1}$ European University of Lefke, Faculty of Agricultural Sciences and Technologies, Department of Horticulture, \\ 99780, Gemikonağı, Northern Cyprus, via Mersin 10 Turkey \\ ${ }^{1}$ https://orcid.org/0000-0002-6074-6395 \\ *Sorumlu yazar e-posta: ibrahimcy84@yahoo.com
}

\section{Article Info}

Received: 07.02.2021 Accepted: 01.06.2021

Online Published 15.09.2021

DOI: 10.29133 yyutbd.876019

\section{Keywords}

Ascorbic acid content,

Mechanical damage,

Minimal processing,

Sensory quality.

\begin{abstract}
Pomegranate (Punica granatum L.) arils are so perishable and have very short storability after extracting from the fruit peel. Therefore, several techniques have been used for the improvement of the arils' storability. Among these techniques, edible films and coatings have a long history in food preservation; where most of the studies have focused on edible coatings. Therefore, present study aimed to test the performance of clove extract incorporated gelatine/glycerine based edible film covered PET packaging on the ready-to-eat 'Wonderful' pomegranate arils. Edible films were prepared in 4 different compositions, including; EF1: only gelatine and glycerine, EF2: gelatine/glycerine with clove extract, EF3: gelatine/glycerine with clove extract and some additives and EF4: gelatine/glycerine with only additives. Un-covered PET packages were then used as a control group. Studies were conducted with 35 boxes (each with 50 arils) in each group, and the boxes were stored at $4 \pm 0.5^{\circ} \mathrm{C}$ and $90-95 \%$ relative humidity for 14 days. Quality parameters were observed with 2-days interval. Results suggested that all of the four edible films are effective in preventing weight loss, mechanical damage, loss in sensory quality, reduction of soluble solids content, decline in titratable acidity and loss of ascorbic acid content of the pomegranate arils. The highest efficacy was noted from EF2 and EF3, which were incorporated with clove extract. According to the measured parameters, the edible films together with the PET packaging make it possible to store arils for 10 days with acceptable sensory quality.
\end{abstract}

\section{Karanfil Ekstraktı Karıştırılan Jelatin/Gliserin Bazlı Yenilebilir Film ile Kapatılan PET Ambalajın Tüketime Hazır 'Wonderful' Nar Taneleri (Punica granatum L.) Üzerindeki Etkileri}

\section{Makale Bilgileri}

Geliș: 07.02.2021

Kabul: 01.06.2021

Online Yayınlanma 15.09.2021

DOI: 10.29133/yyutbd.876019

Anahtar Kelimeler

Askorbik asit miktarı,

Mekanik hasar,

Minimum işlem,
Öz: Nar (Punica granatum L.) taneleri kolay bozulabilir olduğundan, meyvenin kabuklarından çıkarıldıktan sonra depolanma süresi kısalmaktadır. Dolayısıyla tanelerin depolama süresi ve kalitesinin iyileştirilmesi için çeşitli teknikler kullanılmaktadır. Bu teknikler arasında, gıda muhafazasında uzun bir geçmişi olan yenilebilir filmler ve yenilebilir kaplamalar yer almakta olup, yapılan çalışmalarda daha çok yenilebilir kaplamalarla odaklanılmıştır. Bu nedenle, mevcut çalışma, tüketime hazır 'Wonderful' nar taneleri üzerinde PET ambalajı ile karanfil ekstraktı içeren jelatin/gliserin bazlı yenilebilir film kombinasyonunun performansını test etmeyi amaçlamıştır. Yenilebilir filmler 4 farklı kompozisyonda; EF1: sadece jelatin ve gliserin, EF2: karanfil ekstrakt1 
içeren jelatin/gliserin, EF3: karanfil ekstraktı ve bazı katkı maddeleri içeren jelatin/gliserin ve EF4: sadece katkı maddeleri içeren jelatin/gliserin hazırlanmıştır. Yenilebilir film kaplanmamış ambalajlar ise kontrol grubu olarak kullanılmıştır. Her uygulama grubunda 35 kutu (her birinde 50 adet nar tanesi) ile çalışmalar yapılmış ve kutular 14 gün boyunca $4 \pm 0.5^{\circ} \mathrm{C}$ ve $\% 90-95$ bağıl nemde saklanmıştır. Muhafaza süresi boyunca 2 gün aralıklarla kalite parametreleri gözlemlenmiştir. Sonuçlar, dört yenilebilir filmin tamamının nar tanelerinde ağırlık kaybını, mekanik hasar oluşmasını, duyusal kalite kaybını, suda çözünebilir kuru madde miktarı kaybını, titre edilebilir asitlik kaybını ve askorbik asit içeriğindeki azalmayı önlemede etkili olduğunu göstermiştir. En yüksek etkinlik, karanfil ekstraktı ile birleştirilen EF2 ve EF3'te kaydedilmiştir. Ölçülen parametreler doğrultusunda, PET ambalaj ile birlikte kullanılan yenilebilir filmlerin nar tanelerinin kabul edilebilir duyusal kalitesini 10 gün boyunca koruyabildiğini göstermiştir.

\section{Introduction}

Pomegranate (Punica granatum L.) fruits has a long history of cultivation, whereas their production \& consumption had increased since the end of 20th Century due to the scientifically confirmed health benefits and high anti-inflammatory potential (Lansky and Newman, 2007; Çelik et al., 2019; Kahramanoğlu, 2019). Besides to that, pomegranate fruits have unique sensory qualities, high antioxidant capacities and diverse $\&$ abundant phytochemicals, which increased the consumers' interests on pomegranate fruits (Munhuweyi et al., 2017). The main problems regarding the consumption of the pomegranate fruit, is its time-consuming (hassle) characteristic of aril extraction. Furthermore, fruits with high phytochemicals (Okatan and Colak, 2019) and minimally processed ready-to-eat pomegranate arils have known to address this issue and be very popular in the market (Lopez-Rubira, 2005). However, mechanical damages (tissue wounding and aril squashing) increase the susceptibility of arils to storage conditions (Erkan and Kader, 2011). Mechanical damage induces the respiration rate, alters the metabolic activity, increase the weight loss and deteriorate the sensory quality characteristics (Venkataramudu et al., 2018). Overall, the storability of the pomegranate arils decreases to 3-5 days, even under cold storage conditions. The mechanical damage of the arils has also been reported to exude juice fluids, which is a favourable condition for microbial decay (Rodov et al., 2005).

Sanitizing is among the most important protection method against microbial load in minimally processed ready-to-eat arils, whereas the temperature reduction (cold storage), use of antioxidants and atmospheric gaseous control (i.e. modified atmosphere packaging: MAP) are the other important methods (Sepulveda et al., 2000). In such a research Ayhan and Ertürk (2009) reported that the MAP with gas compositions of $70 \% \mathrm{O}_{2}+10 \% \mathrm{CO}_{2}+20 \% \mathrm{~N}_{2}$ prolongs the shelf life of pomegranate arils to 15-18 days. However, Sutherland et al. (2010) reported that, total production of plastic resins had an increase of 25 -fold since $1970 \mathrm{~s}$, where only $5 \%$ of all were recycled. This is an important problem for the natural ecosystems because of its accumulation in the environment. The increase in the consumer awareness on chemical residues and environmental hazards had increased the demand for natural and sustainable materials in food packaging (Mahalik and Nambiar, 2010). Moreover, edible coatings and films may enhance or even replace some of those packaging techniques by providing a barrier against atmospheric gaseous and moisture (Kasapoğlu and Törnük, 2018; Kahramanoğlu et al., 2020). Therefore, testing of edible films alone or in combination with plastic packaging would help to reduce the use of plastics in case of successful results. The edible coatings (EC) are thin layers of biodegradable coating materials, and edible films (EF) are thin layers of the same biodegradable materials. The main difference between these materials is that, EC is applied in liquid form by immersing the fruits in, while $\mathrm{EF}$ is produced from the biodegradable materials as solid sheets, and applied as films by covering/packing/wrapping the fruits (McHugh, 2000). These biodegradable edible films are generally made from biopolymers, including lipids (Hassan et al., 2018), protein (Tkaczewska, 2020) and on polysaccharides such as cellulose, chitosan, starch and pectin (Niu et al., 2021). Among proteins, a denaturized animal protein collagen, the gelatine, is also known to have excellent film-forming properties (Limpisophon et al., 2010). Its optical properties are good and have high mechanical strength (Podshivalov et al., 2017). Incorporation of glycerol into gelatine was also noted to improve its potential 
advantages (Niu et al., 2021). Moreover, it was also previously noted that the incorporation of Nigella sativa oil into a starch-based edible coating improves the storage quality of pomegranate arils $(\mathrm{Oz}$ and Ulukanli, 2012). Plant essential oils (i.e. lavender oil) alone or incorporation with some other materials (i.e. methyl jasomate) were also suggested to improve storability of fruits (Çavuşoğlu et al., 2020).

Although, there have been numerous studies with edible films and coatings on food preservation, there are limited studies with pomegranate arils, where most of them are with edible coatings. In such study, Ozdemir and Gokmen (2017) noted that the edible coating with a mixture of chitosan and ascorbic acid, improves the shelf life of pomegranate arils. It is also well-known that the chemical composition of the coating or film materials have important influence on the antifungal and preservative characteristics of the materials (Kahramanoğlu et al., 2020). Clove (Eugenia carophyllata) is a rich source of phenolics, mostly eugenol and gallic acid, and is being used for centuries as food preservative (Cortés-Rojas et al., 2014). The aqueous extracts of clove has been reported to have very high antioxidant and antifungal activity (Gülçin et al., 2004; Chatterjee and Bhattacharjee, 2013). In line with this information, present study aimed to test the performance of aqueous clove extract incorporated gelatine/glycerine based edible film covered PET (Polyethylene Terephthalate) packaging on the readyto-eat 'Wonderful' pomegranate arils.

\section{Materials and Methods}

\subsection{Study materials}

Fruit samples of current study were collected from a 12-year-old pomegranate orchard, found in the Yayla village of Northern Cyprus. The orchard is composed of 'Wonderful' cultivar pomegranate trees, designed with a $5 \times 5 \mathrm{~m}$ distance. The fruits were hand harvested on $2 \mathrm{nd}$ of November 2020 and immediately (in 30 minutes) brought to the laboratory of Research and Implementation Farm of European University of Lefke. The soluble solids content (SSC) of the harvested fruits was noted as $18.12 \%$ with a titratable acidity (TA) of $1.75 \%$. The other materials of the study are clove, gelatine and glycerol. These materials were purchased from a local shop. Glycerine with a $95 \%$ of glycerol was used in the current studies.

\subsection{Pomegranate aril processing}

To extract the arils, the outer peel of the fruits was cut by using a sharp knife and removed by hand pressing. Care was taken to prevent damage on the arils. The arils were then manually extracted and put in large sterilized boxes. To avoid any possible contamination, polyethylene hand gloves were used during all processes.

\subsection{Edible film preparation and packaging}

Edible films of present study were prepared according to the methods described in Table 1. Totally 4 different edible films and an un-covered control group were tested in present studies. Studies were conducted with completely randomized design. The arils, which were extracted according to the above-described methods, were divided into 5 groups (belonging to the treatments) each containing 1750 arils. Each group was composed of 35 boxes (each with 50 arils). Therefore, 5 boxes (replications) for each treatment were used in each analysis period (totally 7). These boxes are made up from polyethylene terephthalate (PET) plastic materials and are circle in shape with a radius of $5 \mathrm{~cm}$ and a height of $5 \mathrm{~cm} .50$ arils were put in each of these boxes carefully and they were (except the control) covered with the edible films. The film materials were dressed up from the top to the sides of the boxes and tied with a rubber. Then, the boxes were all put in a chamber adjusted to a temperature of $4 \pm 0.5$ ${ }^{\circ} \mathrm{C}$ and $90-95 \%$ relative humidity and stored for 14 days. 
Table 1. Preparation of edible films

\begin{tabular}{|c|c|c|}
\hline $\begin{array}{l}\text { Short } \\
\text { name }\end{array}$ & $\begin{array}{l}\text { Long } \\
\text { name }\end{array}$ & Description of preparation \\
\hline EF1 & Edible film & $\begin{array}{l}12.5 \mathrm{ml} \text { gelatine and } 3 \mathrm{ml} \text { glycerine were dissolved in } 500 \mathrm{ml} \text { of distilled water, } \\
\text { until } 80{ }^{\circ} \mathrm{C} \text { and stirred for } 10 \mathrm{~min} \text { until completely gelatinized. Hereafter, the } \\
\text { solution was casted (in the thinnest possible thickness) onto a plate ( } 15 \mathrm{x} 15 \\
\mathrm{~cm} \text { ), and dried at } 40^{\circ} \mathrm{C} \text { for } 36 \mathrm{~h} \text { in an incubator (slightly modified from Niu et } \\
\text { al. (2021)). }\end{array}$ \\
\hline EF2 & $\begin{array}{l}\text { Edible film } \\
+ \text { clove }\end{array}$ & $\begin{array}{l}\text { First of all, } 5 \mathrm{~g} \text { of clove was mixed with } 500 \mathrm{ml} \text { of water and the mixture was } \\
\text { heated until } 100{ }^{\circ} \mathrm{C} \text { and kept for } 30 \mathrm{~min} \text { at that temperature. It was then filtered } \\
\text { and cooled down to } 80{ }^{\circ} \mathrm{C} \text {. Afterwards, } 12.5 \mathrm{ml} \text { gelatine and } 3 \mathrm{ml} \text { glycerine } \\
\text { were added and the same procedure was followed with EF } 1 \text {. }\end{array}$ \\
\hline EF3 & $\begin{array}{l}\text { Edible film } \\
+ \text { clove }+ \\
\text { additives }\end{array}$ & $\begin{array}{l}5 \mathrm{~g} \text { of clove was mixed with } 500 \mathrm{ml} \text { of water and the mixture was heated until } \\
100^{\circ} \mathrm{C} \text { and kept for } 30 \text { min at that temperature. It was then filtered and } 2 \mathrm{~g} \text { of } \\
\text { Arabic gum was added and stirred for } 10 \text { more minutes at same temperature. } \\
\text { The solution was then cooled down to } 80^{\circ} \mathrm{C} \text {. Hereafter, together with } 12.5 \mathrm{ml} \\
\text { gelatine and } 3 \mathrm{ml} \text { glycerine; } 0.5 \mathrm{~g} \text { citric acid and } 0.5 \mathrm{~g} \text { vitamin } \mathrm{C} \text { were also } \\
\text { mixed into the solution. It was stirred for } 10 \text { min until completely gelatinized. } \\
\text { Hereafter, the solution was casted onto a plate }\left(15^{*} 15 \mathrm{~cm}\right) \text {, and dried at } 40^{\circ} \mathrm{C} \\
\text { for } 36 \mathrm{~h} \text { in an incubator }\end{array}$ \\
\hline EF4 & $\begin{array}{l}\text { Edible film } \\
+ \text { additives }\end{array}$ & $\begin{array}{l}\text { This material was prepared by following a similar method of EF3, by not } \\
\text { incorporating clove into the solution. }\end{array}$ \\
\hline
\end{tabular}

\subsection{Quality analysis}

A total of 5 boxes were used for analysis at each measurement point (day 2, 4, 6, 8, 10, 12 and 14). The total weight of 50 arils per boxes were determined with a digital balance (sensitive to $0.01 \mathrm{~g}$ ). Thus, at each measurement point, the final weights were determined by following the same way and the weight loss was calculated according to the standard ratio method. Firstly, final weight was subtracted from the initial weight to find the weight lost. Then the weight lost was divided to the starting weight and multiplied by 100 ([weight lost/initial] x 100). Hereafter, arils with mechanical damage (chilling, bruising, browning and juice leakage) (Aliasgarian et al., 2013) were counted for each box and used to calculate the percentage of damage. Same standard ratio method was followed by dividing the number of damaged arils to the total arils and multiplying with 100. The 9-point hedonic scale of Xing et al. (2011) was then used to assess the sensory acceptability of the pomegranate arils. The texture, colour and flavour were assessed for sensory quality. The scale meanings from 1 to 9 were recommended as 1 : poor, 3: fair, 5: good, 7: very good and 9: excellent.

Soluble solids concentration (SSC), titratable acidity (TA) and ascorbic acid (AsA) were all assessed one for each replication (box: a mixture of 50 arils). The juice mixture of 50 arils were used to do measurements. SSC (\%) was assessed with a hand refractomer. TA was measured according to the standard titration method. Juice samples were dissolved in distilled water in a ratio of 10:50 and then titrated with $0.1 \mathrm{~N} \mathrm{NaOH}$ to an endpoint of $\mathrm{pH}$ 8.1. Then, below given formula was used to determine the TA as $\mathrm{g} 100 \mathrm{~g}^{-1}$ of citric acid:

$$
\mathrm{TA}(\%)=\left(\frac{(\mathrm{mL} \text { of } \mathrm{NaOH} \text { used }) \times 0.0064}{\mathrm{~mL} \text { of sample used }}\right) \times 100
$$

Finally, the AsA content of each replication was assessed through standard titration with 2,6dichlorophenol indophenol. Five millilitres of juice was made up to $100 \mathrm{~mL}$ using $3 \%$ metaphosphoric acid $\left(\mathrm{HPO}_{3}\right)$. The sample was filtered with whatman No. 1 filter paper. $10 \mathrm{~mL}$ of solution was then taken into a conical flask and titrated with dye till pink colour appeared. The titrations were recorded and the unit of AsA expressed in mg $100 \mathrm{~g}^{-1}$ (Ranganna, 1999). 


\subsection{Data analysis}

Raw data of the experiments were hand written into Microsoft Excel and summarized by calculating the means and standard deviations of each treatment at each storage duration. Then line graphics were used to clearly present the data. Since the completely randomized design was used in the present study, the comparison of the treatments for different storage time was assessed with one-way analysis of variance (ANOVA) by using SPSS 22.0 and in the case of statistical difference, the mean separations were done with Tukey's HSD test at $\mathrm{P}<0.05$ statistical significance.

\section{Results}

\subsection{Effects on physical quality parameters}

All kinds of edible films (as a covering material of PET packaging) had been found to have a slight to moderate effect on the weight of ready-to-eat pomegranate arils (Figure 1). As expected, the weight loss increased during the storage, however was found to be higher at the un-covered control arils. At the first measurement point ( 2 days of storage), the weight loss was $3.58 \%$ at the un-covered fruits and was $1.83 \%$ and $1.84 \%$ at the EF2 and EF3.

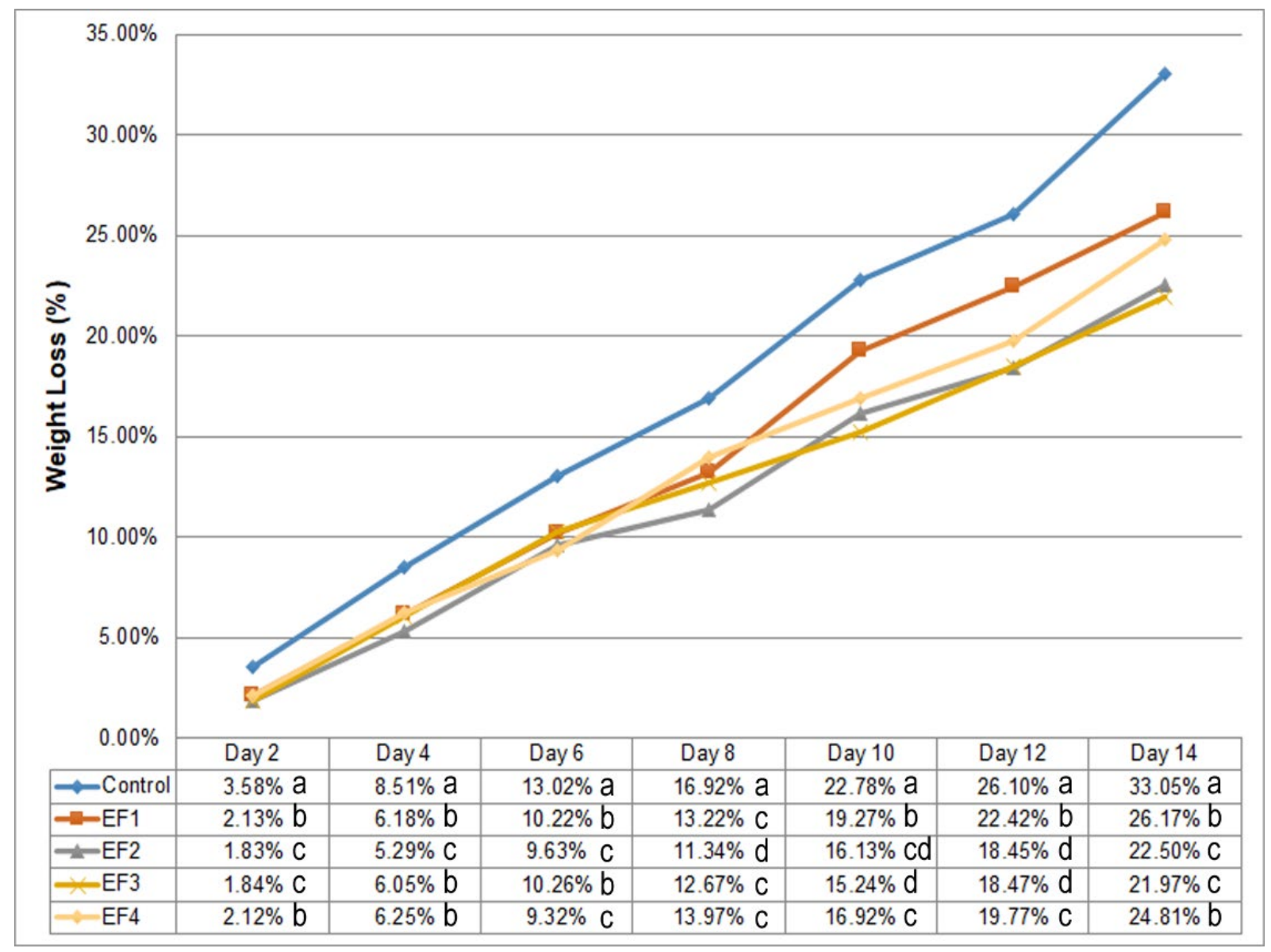

Figure 1. Change in weight loss (\%) of ready-to-eat pomegranate arils as response to clove extract incorporated gelatine/glycerol based edible film packaging. Different letters next to the means below the lines of each storage point, represents significant differences among the treatments for each measurement point according to Tukey's HSD test at $\mathrm{P}<0.05$.

Similar trend had been found to continue till the end of the storage period. At day 4, the weight loss of the un-covered arils found to be more than the twice of the day 2 . All of the edible films, had significant influence on the prevention of the loss in the aril weight. At the end of storage duration (14 day) the highest weight loss was measured from the un-covered arils as $33.05 \%$. The highest efficacy in 
prevention of the weight was noted from the EF 3, which includes both clove and additives. No significant difference was observed between this treatment and EF2, which only include clove but not additives, at the end of the storage.

The first mechanical damage had been observed after 4 days of storage on the un-covered control arils (Figure 2). However, all of the four edible films had been observed to prevent mechanical damage until 6 days of storage. The EF2 and EF3 were also noted to prevent mechanical damage for 8 days of storage. After that day (day 8), the mechanical damage of the EF1 and EF4 increased, while the EF2 and EF3 were noted to be more effective. These results are in accordance with the weight loss results. At day 8 , the mechanical damage was close to $40 \%$ in control arils which means a substantial reduction in the acceptability of the arils. At the end of the storage duration (day 14), the un-covered control fruits had $100 \%$ mechanical damage, while at the same day, mechanical damage was only $33.20 \%$ and $34.00 \%$, respectively, for $\mathrm{EF} 3$ and $\mathrm{EF} 2$.

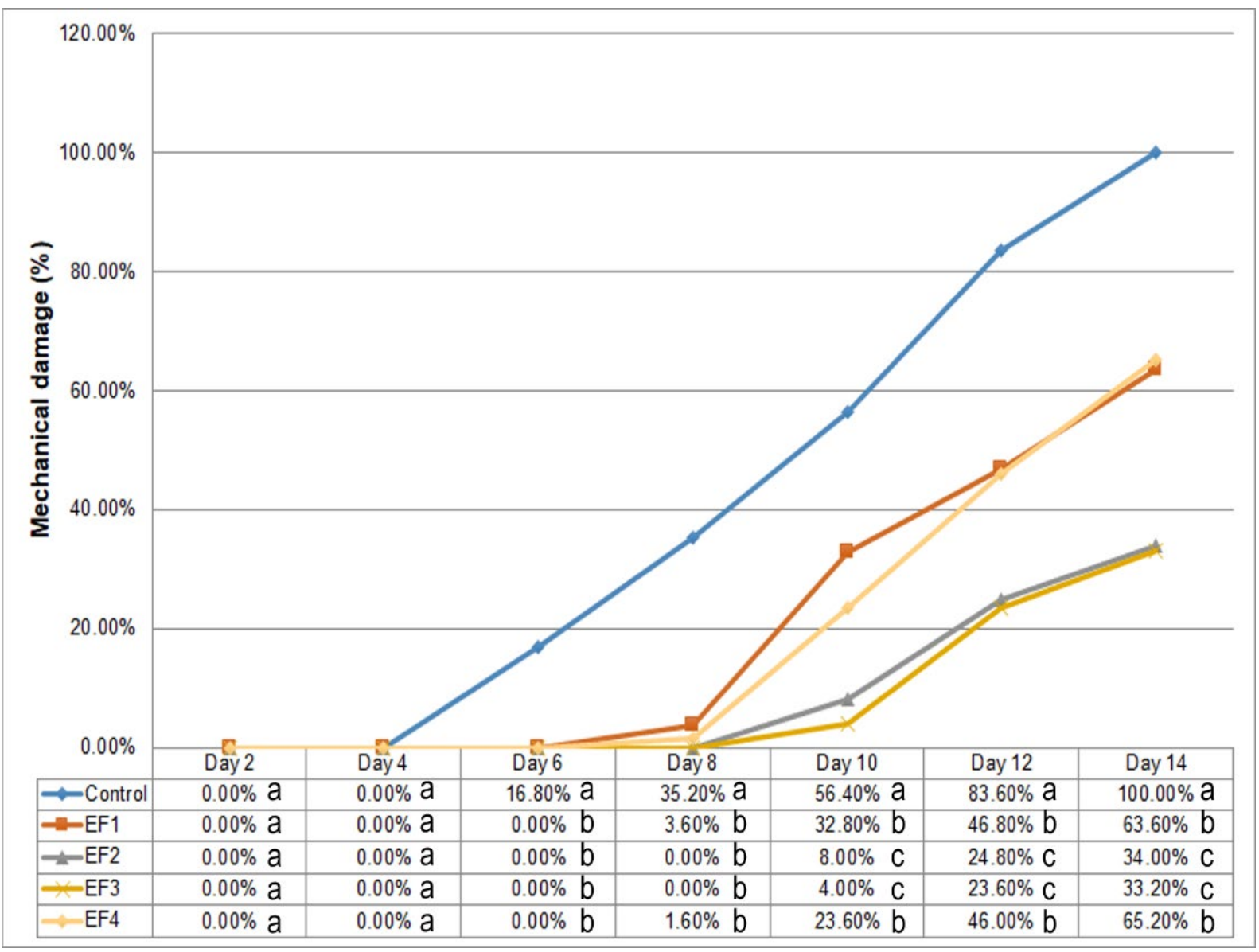

Figure 2. Change in mechanical damage (\%) of ready-to-eat pomegranate arils as response to clove extract incorporated gelatine/glycerol based edible film packaging. Different letters next to the means below the lines of each storage point, represents significant differences among the treatments for each measurement point according to Tukey's HSD test at $\mathrm{P}<0.05$.

Sensory quality is very important for the ready-to-eat pomegranate arils. The reduction in the sensory quality reduces the marketability of the products. The results of present study showed that the sensory quality decreased during storage, but decreased slowly at the packed arils as compared with the un-covered arils (Figure 3). At day 6, average sensory acceptability of the un-covered arils decreased to 6.40 and at day 8, it reduced to 3.60 (fair). According to the results obtained, the overall sensory acceptability of the arils packed with EF2 and EF3 were over 5.00 (good) still at the day 10. These results are very important for the effectiveness of the edible film packaging. According to the sensory acceptability results, it can be accepted that the EF2 and EF3 can prolong the storability of the arils for 10 days. 


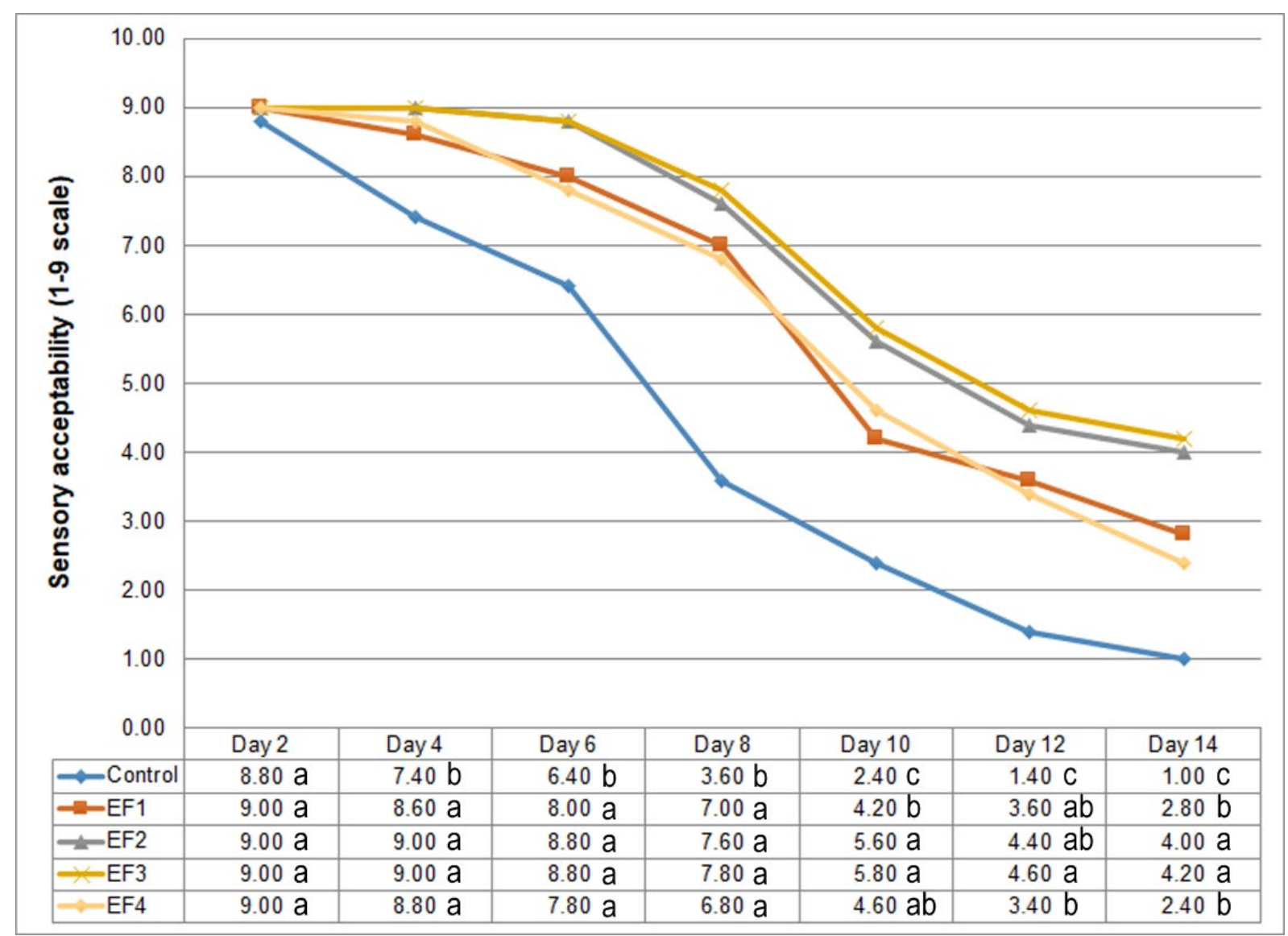

Figure 3. Change in sensory acceptability (1-9 scale) of ready-to-eat pomegranate arils as response to clove extract incorporated gelatine/glycerol based edible film packaging. Different letters next to the means below the lines of each storage point, represents significant differences among the treatments for each measurement point according to Tukey's HSD test at $\mathrm{P}<0.05$.

\subsection{Effects on bio-chemical quality parameters}

Both the SSC and TA are very important for the fruit flavour. As a general knowledge, both of them change during storage and significantly affect the consumers' acceptability. In this experiment, the arils SSC had been noted to have a continuous increase during storage, while the TA had a reverse trend (Table 2).

The SSC of the arils was measured as $18.12 \%$ at the first day of harvest. In 14 days of storage, it was increased to $25.32 \%$ at the un-covered control arils. This is mainly a result of the high weight loss and reduce the acceptability of the arils. Since the fruit SSC was measured as percentage, the decrease in water content caused an increase in the SSC (as \%). This is because, most of the weight loss in pomegranate arils was occurred as a loss of water due to transpiration. There is also a loss of carbohydrates and soluble sugars due to respiration. The SSC was also increased in other applications, which were packed in edible films, but the increase was less due to the less loss of water. At the end of the storage period, the lowest SSC (so the lowest change) was noted from the EF3 with $22.64 \%$ and followed by EF2 with $23.00 \%$. On the other hand, the TA of the arils began from $1.75 \%$ (day 0 ) and decreased to $0.79 \%$ at the un-covered arils at the end of storage period. The edible films were again found to slow down the loss of TA during storage. The highest influence was noted from the EF2 and EF3 and the arils in these treatments were noted to have highest TA content at the end of the storage period. The reduction in TA caused an increase in the SSC/TA ratio, which cause an un-pleasant sweetness in the arils. At the day 0, the SSC/TA was only 10.35, but was increased to 32.05 at the uncovered arils in 14 days of cold storage. At the same time, the SSC/TA ratio of the arils packed in EF3 was only 15.94. Finally, the AsA content was found to have an increase during the first days of storage and then decreased with the development of the aril deterioration. The initial AsA content was $59.46 \mathrm{mg}$ 
$100 \mathrm{~g}-1$ and decreased to $31.89 \mathrm{mg} 100 \mathrm{~g}-1$ at the un-covered control arils. Similar with the other results, the edible films were found to have significant influence on the prevention of the loss of AsA. Thus, the

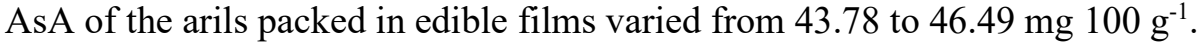

Table 2. Change in SSC (\%), TA (\%) and AsA (mg $\left.100 \mathrm{~g}^{-1}\right)$ of ready-to-eat pomegranate arils as response to clove extract incorporated gelatine/glycerol based edible film packaging

\begin{tabular}{lclllllll}
\hline Treatments & Day 0 & Day 2 & Day 4 & Day 6 & Day 8 & Day 10 & Day 12 & Day 14 \\
\hline SSC & & & & & & & & \\
Control & $18.12 \mathrm{a}$ & $18.72 \mathrm{a}$ & $20.56 \mathrm{a}$ & $21.32 \mathrm{a}$ & $22.44 \mathrm{a}$ & $23.32 \mathrm{a}$ & $24.28 \mathrm{a}$ & $25.32 \mathrm{a}$ \\
EF1 & $18.12 \mathrm{a}$ & $18.44 \mathrm{ab}$ & $19.12 \mathrm{~b}$ & $20.04 \mathrm{bc}$ & $21.24 \mathrm{bc}$ & $22.20 \mathrm{~b}$ & $23.28 \mathrm{~b}$ & $24.16 \mathrm{~b}$ \\
EF2 & $18.12 \mathrm{a}$ & $18.32 \mathrm{~b}$ & $18.60 \mathrm{~b}$ & $19.32 \mathrm{~cd}$ & $20.24 \mathrm{~cd}$ & $21.16 \mathrm{c}$ & $22.24 \mathrm{c}$ & $23.00 \mathrm{c}$ \\
EF3 & $18.12 \mathrm{a}$ & $18.40 \mathrm{ab}$ & $18.56 \mathrm{~b}$ & $19.08 \mathrm{~d}$ & $19.84 \mathrm{~d}$ & $20.76 \mathrm{c}$ & $21.80 \mathrm{c}$ & $22.64 \mathrm{c}$ \\
EF4 & $18.12 \mathrm{a}$ & $18.36 \mathrm{ab}$ & $19.20 \mathrm{~b}$ & $20.08 \mathrm{~b}$ & $21.40 \mathrm{ab}$ & $22.28 \mathrm{~b}$ & $23.36 \mathrm{~b}$ & $24.24 \mathrm{~b}$ \\
\hline TA & & & & & & & & \\
Control & $1.75 \mathrm{a}$ & $1.67 \mathrm{a}$ & $1.59 \mathrm{~b}$ & $1.42 \mathrm{c}$ & $1.25 \mathrm{c}$ & $1.13 \mathrm{~d}$ & $0.91 \mathrm{~d}$ & $0.79 \mathrm{~d}$ \\
EF1 & $1.75 \mathrm{a}$ & $1.72 \mathrm{a}$ & $1.67 \mathrm{a}$ & $1.56 \mathrm{~b}$ & $1.44 \mathrm{~b}$ & $1.37 \mathrm{c}$ & $1.34 \mathrm{c}$ & $1.23 \mathrm{c}$ \\
EF2 & $1.75 \mathrm{a}$ & $1.72 \mathrm{a}$ & $1.70 \mathrm{a}$ & $1.64 \mathrm{a}$ & $1.54 \mathrm{a}$ & $1.45 \mathrm{~b}$ & $1.43 \mathrm{~b}$ & $1.33 \mathrm{~b}$ \\
EF3 & $1.75 \mathrm{a}$ & $1.72 \mathrm{a}$ & $1.70 \mathrm{a}$ & $1.64 \mathrm{a}$ & $1.55 \mathrm{a}$ & $1.51 \mathrm{a}$ & $1.48 \mathrm{a}$ & $1.42 \mathrm{a}$ \\
EF4 & $1.75 \mathrm{a}$ & $1.72 \mathrm{a}$ & $1.65 \mathrm{a}$ & $1.55 \mathrm{~b}$ & $1.43 \mathrm{~b}$ & $1.36 \mathrm{c}$ & $1.33 \mathrm{c}$ & $1.24 \mathrm{c}$ \\
\hline SSC/TA & & & & & & & & \\
Control & $10.35 \mathrm{a}$ & $11.21 \mathrm{a}$ & $12.93 \mathrm{a}$ & $15.01 \mathrm{a}$ & $17.95 \mathrm{a}$ & $20.64 \mathrm{a}$ & $26.68 \mathrm{a}$ & $32.05 \mathrm{a}$ \\
EF1 & $10.35 \mathrm{a}$ & $10.72 \mathrm{a}$ & $11.45 \mathrm{~b}$ & $12.85 \mathrm{~b}$ & $14.75 \mathrm{~b}$ & $16.20 \mathrm{~b}$ & $17.37 \mathrm{~b}$ & $19.64 \mathrm{~b}$ \\
EF2 & $10.35 \mathrm{a}$ & $10.65 \mathrm{a}$ & $10.94 \mathrm{~b}$ & $11.78 \mathrm{~b}$ & $13.14 \mathrm{~b}$ & $14.59 \mathrm{c}$ & $15.55 \mathrm{c}$ & $17.29 \mathrm{c}$ \\
EF3 & $10.35 \mathrm{a}$ & $10.70 \mathrm{a}$ & $10.92 \mathrm{~b}$ & $11.63 \mathrm{~b}$ & $12.80 \mathrm{~b}$ & $13.75 \mathrm{c}$ & $14.73 \mathrm{c}$ & $15.94 \mathrm{c}$ \\
EF4 & $10.35 \mathrm{a}$ & $10.67 \mathrm{a}$ & $11.64 \mathrm{~b}$ & $12.95 \mathrm{~b}$ & $14.97 \mathrm{~b}$ & $16.38 \mathrm{~b}$ & $17.56 \mathrm{~b}$ & $19.55 \mathrm{~b}$ \\
\hline AsA & & & & & & & & \\
Control & $59.46 \mathrm{a}$ & $60.54 \mathrm{~b}$ & $62.16 \mathrm{~b}$ & $56.22 \mathrm{~b}$ & $47.03 \mathrm{~b}$ & $43.24 \mathrm{c}$ & $36.22 \mathrm{c}$ & $31.89 \mathrm{~b}$ \\
EF1 & $59.46 \mathrm{a}$ & $65.95 \mathrm{a}$ & $64.86 \mathrm{ab}$ & $62.16 \mathrm{a}$ & $56.76 \mathrm{a}$ & $53.51 \mathrm{ab}$ & $49.73 \mathrm{a}$ & $44.86 \mathrm{a}$ \\
EF2 & $59.46 \mathrm{a}$ & $68.11 \mathrm{a}$ & $65.95 \mathrm{a}$ & $63.24 \mathrm{a}$ & $56.76 \mathrm{a}$ & $52.97 \mathrm{ab}$ & $49.19 \mathrm{ab}$ & $45.41 \mathrm{a}$ \\
EF3 & $59.46 \mathrm{a}$ & $68.11 \mathrm{a}$ & $66.49 \mathrm{a}$ & $62.70 \mathrm{a}$ & $58.92 \mathrm{a}$ & $54.59 \mathrm{a}$ & $49.19 \mathrm{ab}$ & $46.49 \mathrm{a}$ \\
EF4 & $59.46 \mathrm{a}$ & $69.19 \mathrm{a}$ & $68.11 \mathrm{a}$ & $60.54 \mathrm{ab}$ & $54.59 \mathrm{a}$ & $49.73 \mathrm{~b}$ & $45.95 \mathrm{~b}$ & $43.78 \mathrm{a}$ \\
\hline
\end{tabular}

Different letters next to the means below the lines of each storage point, represents significant differences among the treatments for each measurement point according to Tukey's HSD test at $\mathrm{P}<0.05$.

\section{Discussion and Conclusion}

Several researches have reported that the packaging films can affect the headspace gas composition in packed pomegranate arils (Adiletta et al., 2019). However, this change was noted to be slow, due to the low respiration rate of pomegranate arils at low temperatures (Caleb et al., 2013). Therefore, it was expected that the edible films would have also similar effect, which then reduce the respiration rate and delay the quality degradation in the pomegranate arils. Edible films of present study were also found to have a significant influence on the prevention of weight loss. The highest influence was noted from the ones which were incorporated with the clove extract. In a similar study, Hasheminejad and Khodaiyan (2020) suggested that the clove essential oil loaded chitosan nanoparticles as edible coating (but not film) improve the arils storage quality and also reduce the weight loss. The results of these authors support the findings of the present study. The protection of the weight loss in edible films is mainly associated with the formation of a barrier against gas and water vapor (Brasil et al., 2012).

Edible films in present study were also found to have positive influence on the prevention of mechanical damage and sensory acceptability. Similar results for clove essential oil incorporated edible coatings were noted by Hasheminejad and Khodaiyan (2020) for pomegranate arils. The cinnamon oil, for example, was also noted to improve the sensory quality of fresh-cut papaya before (Brasil et al., 2012). In this study, the SSC content of the arils had been found to increase during storage. Generally, the SSC values decrease due to the sugar degradation during storage (Fawole and Opara, 2013), but Kahramanoğlu et al. (2018) recommended that if there is high reduction in the weight loss, this may cause an increase the SSC values, as it is the percentage of soluble contents to the total volume. 
The TA values had been reported to decrease during storage at the pomegranate arils as a result of the consumption of organic acids during respiration (Fawole and Opara, 2013). According to the results of present study, clove extract incorporated gelatine/glycerol based edible films delayed the change in SSC/TA and improved the consumer acceptability of the arils (Song et al., 2016). Similarly, clove essential oil in edible coatings reported to delay the changes in SSC/TA by Hasheminejad and Khodaiyan (2020). Present study also suggested that the edible films delay the decrease in AsA. Similar results were previously noted for chitosan, where the chitosan edible coatings delayed the reduction in the AsA (Munhuweyi et al., 2017).

Overall results of current research suggested that the clove extract incorporated gelatine/glycerol based edible film packaging improves the storage quality of ready-to-eat 'Wonderful' pomegranate arils. According to the measured parameters, the PET packaging covered with edible films make it possible to store arils for 10 days with acceptable sensory quality. Although the sensory acceptability results of current study include microbial observation, a laboratory analysis for microbial decay is also important to test in the future studies. Comparison and discussion of the results also made it possible to come up with an idea that, covering the arils within edible films, like a sweet candy may provide better results and may help to reduce the plastic use, but needs a scientific confirmation.

\section{References}

Adiletta, G., Petriccione, M., Liguori, L., Zampella, L., Mastrobuoni, F., \& Di Matteo, M. (2019). Overall quality and antioxidant enzymes of ready-to-eat 'Purple Queen' pomegranate arils during cold storage. Postharvest Biology and Technology, 155, 20-28. doi:10.1016/j.postharvbio.2019.05.008

Aliasgarian, S., Ghassemzadeh, H. R., Moghaddam, M., \& Ghaffari, H. (2013). Mechanical damage of strawberry during harvest and postharvest operations. World Applied Sciences Journal, 22(7), 969-974. doi:10.1515/ata-2015-0001

Ayhan, Z., \& Estürk, O. (2009). Overall quality and shelf life of minimally processed and modified atmosphere packaged "ready-to-eat" pomegranate arils. Journal of Food Science, 74(5), 399405. doi:10.1111/j.1750-3841.2009.01184.x.

Brasil, I. M., Gomes, C., Puerta-Gomez, A., Castell-Perez, M. E., \& Moreira, R. G. (2012). Polysaccharide-based multilayered antimicrobial edible coating enhances quality of fresh-cut papaya. LWT-Food Science and Technology, 47(1), 39-45. doi:10.1016/j.lwt.2012.01.005

Caleb, O. J., Mahajan, P. V., Manley, M., \& Opara, U. L. (2013). Evaluation of parameters affecting modified atmosphere packaging engineering design for pomegranate arils. International Journal of Food Science and Technology, 48 (11), 2315-2323. doi:10.1111/ijfs.12220

Chatterjee, D., \& Bhattacharjee, P. (2013). Comparative evaluation of the antioxidant efficacy of encapsulated and un-encapsulated eugenol-rich clove extracts in soybean oil: Shelf-life and frying stability of soybean oil. Journal of Food Engineering, 117(4), 545-550. doi: 10.1016/j.jfoodeng.2012.11.016

Cortés-Rojas, D. F., de Souza, C. R. F., \& Oliveira, W. P. (2014). Clove (Syzygium aromaticum): a precious spice. Asian Pacific journal of tropical biomedicine, 4(2), 90-96. doi:10.1016/S22211691(14)60215-X

Çavuşoğlu, Ş., İşlek, F., Yilmaz, N., \& Tekin, O. (2020). The Effects of Methyl Jasmonate, Cytokinin and Lavender Oil Applications on Postharvest Physiology in Apricot Fruit (Prunus armeniaca L.). YYU Journal of Agricultural Science, 30(1), 136-146. doi:10.29133/yyutbd.679851

Çelik, F., Gündoğdu, M., \& Zenginbal, H. (2019). Profile of Organic Acid and Vitamin C in Fruits of Some Pomegranate Genotypes. YYU Journal of Agricultural Science, 29(3), 489-495. doi:10.29133/yyutbd.517177

Erkan, M., \& Kader, A. A. (2011). Pomegranate (Punica granatum L.). In E. M. Yahia (Ed), Postharvest biology and technology of tropical and subtropical fruits, volume 4, mangosteen to white sapote (pp. 231-249). Cambridge: Woodhead Publishing.

Fawole, O. A., \& Opara, U. L. (2013). Effects of storage temperature and duration on physiological responses of pomegranate fruit. Industrial Crops and Products, 47, 300-309. doi:10.1016/j.indcrop.2013.03.028 
Gülçin, İ., Şat, İ. G., Beydemir, Ş., Elmastaş, M., \& Küfrevioğlu, Ö. İ. (2004). Comparison of antioxidant activity of clove (Eugenia caryophylata Thunb) buds and lavender (Lavandula stoechas L.). Food chemistry, 87(3), 393-400. doi:10.1016/j.foodchem.2003.12.008

Hasheminejad, N., \& Khodaiyan, F. (2020). The effect of clove essential oil loaded chitosan nanoparticles on the shelf life and quality of pomegranate arils. Food Chemistry, 309, 125520. doi:10.1016/j.foodchem.2019.125520

Hassan, B., Chatha, S. A. S., Hussain, A. I., Zia, K. M., \& Akhtar, N. (2018). Recent advances on polysaccharides, lipids and protein based edible films and coatings: A review. International Journal of Biological Macromolecules, 109, 1095-1107. doi:10.1016/j.ijbiomac.2017.11.097

Kahramanoğlu, İ. (2019). Trends in pomegranate sector: production, postharvest handling and marketing. International Journal of Agriculture Forestry and Life Sciences, 3(2), 239-246.

Kahramanoğlu, İ., Aktaş, M., \& Gündüz, Ş. (2018). Effects of fludioxonil, propolis and black seed oil application on the postharvest quality of "Wonderful" pomegranate. Plos one, 13(5), e0198411. doi:10.1371/journal.pone.0198411

Kahramanoğlu, İ., Usanmaz, S., Alas, T., Okatan, V., \& Wan, C. (2020). Combined effect of hot water dipping and Cistus creticus L. leaf extracts on the storage quality of fresh Valencia oranges. Folia Horticulturae, 32(2), 337-350. doi:10.2478/fhort-2020-0029

Kasapoğlu, E. D., \& Törnük, F. (2018). Microorganism Incorporated Edible Films and Coatings. YYU Journal of Agricultural Science, 28(4), 518-529. doi:10.29133/yyutbd.449424

Lansky, E. P., \& Newman, R. A. (2007). Punica granatum (pomegranate) and its potential for prevention and treatment of inflammation and cancer. Journal of Ethnopharmacology, 109, 177e206. doi:10.1016/j.jep.2006.09.006

Limpisophon, K., Tanaka, M., \& Osako, K. (2010). Characterization of gelatin-fatty acid emulsion films based on blue shark (Prionace glauca) skin gelatin. Food Chemistry, 122(4), 1095-1101. doi:10.1016/j.foodchem.2010.03.090

Lopez-Rubira, V., Conesa, A., Allende, A., \& Artes, F. (2005). Shelf life and overall quality of minimally processed pomegranate arils modified atmosphere packaged and treated with UV-C. Postharvest Biology and Technology, 37(2), 174-185. doi:10.1016/j.postharvbio.2005.04.003

Mahalik, N. P., \& Nambiar, A. N. (2010). Trends in food packaging and manufacturing systems and technology. Trends in Food Science \& Technology, 21(3), $117 \mathrm{e} 128$. doi:10.1016/j.tifs.2009.12.006

McHugh, T. H. (2000). Protein-lipid interactions in edible films and coatings. Food/Nahrung, 44(3), 148-151. doi: 10.1002/1521-3803(20000501)44:3<148::AID-FOOD148>3.0.CO;2-P

Munhuweyi, K., Lennox, C. L., Meitz-Hopkins, J. C., Caleb, O. J., Sigge, G. O., \& Opara, U. L. (2017). Investigating the effects of crab shell chitosan on fungal mycelial growth and postharvest quality attributes of pomegranate whole fruit and arils. Scientia Horticulturae, 220, 78-89. doi:10.1016/j.scienta.2017.03.038

Niu, X., Ma, Q., Li, S., Wang, W., Ma, Y., Zhao, H., \& Wang, J. (2021). Preparation and Characterization of Biodegradable Composited Films Based on Potato Starch/Glycerol/Gelatin. Journal of Food Quality, 6633711. doi:10.1155/2021/6633711

Okatan, V., \& Çolak, A. M. (2019). Chemical and phytochemicals content of barberry (Berberis vulgaris L.) fruit genotypes from Sivasli district of Usak province of western Turkey. Pakistan Journal of Botany, 51(1), 165-170. doi:10.30848/PJB2019-1(5)

Oz, A. T., \& Ulukanli, Z. (2012). Application of edible starch-based coating including glycerol plus oleum nigella on arils from long-stored whole pomegranate fruits. Journal of Food Processing and Preservation, 36(1), 81-95. doi:10.1111/j.1745-4549.2011.00599.x.

Özdemir, K. S., \& Gökmen, V. (2017). Extending the shelf-life of pomegranate arils with chitosanascorbic acid coating. LWT-Food Science and Technology, 76, 172-180. doi:10.1016/j.lwt.2016.10.057

Podshivalov, A., Zakharova, M., Glazacheva, E., \& Uspenskaya, M. (2017). Gelatin/potato starch edible biocomposite films: Correlation between morphology and physical properties. Carbohydrate Polymers, 157, 1162-1172. doi:10.1016/j.carbpol.2016.10.079

Ranganna, S. (1986). Handbook of analysis and quality control for fruit and vegetable products. Tata McGraw-Hill Education. 
Rodov, V., Schmilovitch, Z., Ronen, B., Hoffman, A., Egozi, H., Porat, R., et al. (2005). Mechanically separated pomegranate arils: A new lightly processed fresh product. 5th IFPA poster session at fresh-cut expo. Phoenix: AZ

Sepulveda, E., Galletti, L., Sáenz, C., \& Tapia, M. (2000). Minimal processing of pomegranate var. Wonderful. CIHEAM-Opitions Mediterraneennes, 42, 237-242.

Song, H., Yuan, W., Jin, P., Wang, W., Wang, X., Yang, L., \& Zhang, Y. (2016). Effects of chitosan/nano-silica on postharvest quality and antioxidant capacity of loquat fruit during cold

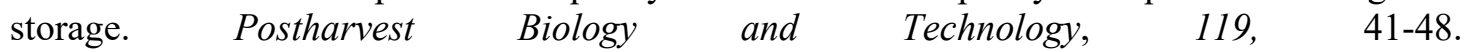
doi:10.1016/j.postharvbio.2016.04.015

Sutherland, W. J., Clout, M., Côté, I. M., Daszak, P., Depledge, M. H., Fellman, L., et al. (2010). A horizon scan of global conservation issues for 2010. Trends in Ecology \& Evolution, 25(1), 17. doi:10.1016/j.tree.2009.10.003

Tkaczewska, J. (2020). Peptides and protein hydrolysates as food preservatives and bioactive components of edible films and coatings-A review. Trends in Food Science \& Technology, 206, 298-311. doi:10.1016/j.tifs.2020.10.022

Venkataramudu, K., Naik, S. R., Viswanath, M., \& Chandramohan, G. (2018). Packaging and storage of pomegranate fruits and arils: A review. International Journal of Chemical Studies, 6(6), 1964-1967.

Xing, Y., Li, X., Xu, Q., Yun, J., Lu, Y., \& Tang, Y. (2011). Effects of chitosan coating enriched with cinnamon oil on qualitative properties of sweet pepper (Capsicum annuum L.). Food Chemistry, 124(4), 1443-1450. doi:10.1016/j.foodchem.2010.07.105 